\title{
Determine heavy metals in water, aquatic plants, and sediment in water systems
}

\author{
Hassan Flefel ${ }^{1,2, *}$, Denis Nokhrin ${ }^{3}$, and Irina Donnik ${ }^{1}$ \\ ${ }^{1}$ Ural State Agrarian University, Department of Infectious and Non-infectious Pathology, 620075 \\ Yekaterinburg, Russia. \\ ${ }^{2}$ Theodor Bilharz Research Institute, Department of Environmental Researches and Medical \\ Malacology, Imbaba, PO Box-30, Giza, Egypt. \\ ${ }^{3}$ Federal State Budgetary Scientific Institution «Ural Federal Agrarian Scientific Research Centre, \\ Ural Branch of Russian Academy of Sciences», 620142 Yekaterinburg, Russia
}

\begin{abstract}
Objective: Biomonitoring pollution of water bodies with heavy metals using evaluation of the level of concentration of heavy metals in water, aquatic plants, and sediments in 9 important rivers and lakes in the water bodies of Yekaterinburg. (Eight rivers and one lake). Methods: Sample preparation for the atomic absorption determination of the acidsoluble "mobile" form of eight metals ( $\mathrm{Mn}, \mathrm{Fe}, \mathrm{Co}, \mathrm{Ni}, \mathrm{Cu}, \mathrm{Zn}, \mathrm{Cd}, \mathrm{Pb}$ ) in the composition of bottom sediments was carried out by the method of wet mineralization in accordance with the Methodological Guidelines the definition of heavy metals. Results: All concentrations of heavy metals in sediments and aquatic plants were higher than in a water sample. Conclusions: Concentrations of all water samples were within acceptable limits established by $\mathrm{WHO}$, while the concentrations of all aquatic plants and sediment were above the acceptable limits of WHO.
\end{abstract}

\section{Introduction}

River ecosystems are under constant pressure from anthropogenic pollutants that come from different locations in the catchment area or at distant locations. Many pollutants containing heavy metals are toxic to aquatic life and output lethal or sub-lethal adverse effects on biota [1]. Heavy metals are considered to be the most serious threats to the environment in general and human health in specific, due to their wide toxicity, degradation caused by living organisms and bioaccumulation[2]. Sediments are good absorbers of heavy metals, and might be also a source of food for benthic organisms. The accumulation of heavy metals in certain conditions leads to environmental damage, moreover might cause a threat to human health through accumulation in the food chain[3]. $\mathrm{Zn}$ and $\mathrm{Cu}$ are very special trace elements because of their double function in plants. Therefore, it is quite difficult to assess their positive or negative effect. It has been found that both have an absolutely necessary effect on plant metabolism function, such as enzymatic activity $[4,5]$.

\footnotetext{
* Corresponding author: hflefel@hotmail.com
} 
While other heavy metals are not needed by plants and might be harmful and considered toxic even at relatively low levels. Such as, cadmium inhibits photosynthesis and absorption of minerals; under the influence of cadmium, the leaves turn yellow and die, which is a symptom of toxicity; mercury slows down the growth and development of roots and prevents photosynthesis[6]. heavy metals exposure may be particulate or dissolved shape disposing to accumulate in river water and sediment[1]. Heavy metal concentrations can becoming different throughout the year in the ecosystem[7]. In the surface water reservoirs the heavy metals might accumulate in the bottom deposits, in the plants and other organisms. Their distribution also can change in the different parts. Water ecosystem consist of many elements, such as different species of fishes and invertebrates, which might be the important sources of food for people, the levels of the content of heavy metals in these products can in the final analysis place human health under the threat. This can occur directly as a result daily use or indirectly because of the lasting effects of accumulation in the food chain[8-10]. The absorption and accumulation of heavy metals by plants can occur in two different ways (1) along with the root system and (2) along the foliage surface[11]. Sediments play the role of both an absorber and a source of pollutants, which can again enter the reservoirs as a result of various recovery processes, which further can lead to possible consequences for the environment and human health[12, 13]. Consequently, sediments can be used as indicators of local pollution conditions. Trace elements can also accumulate in plants. aquatic plants can play an important role in trace elements' accumulation, and removers of trace elements in freshwater ecosystems, because of fast growth, high biomass production, a deep root system, and high tolerance and/or accumulation of a wide range of trace elements[14]. It has been shown that many plant species can accumulate pollutants, which makes them good indicators for monitoring metal pollution at the local scale. On the other they might be a useful tools to reduce pollution by phytoremediation $[15,16]$.

The aim of this study were as follow: to assess the accumulation of heavy metals Fe, Cd, $\mathrm{Co}, \mathrm{Mn}, \mathrm{Cu}, \mathrm{Ni}$, and $\mathrm{Pb}$ in water, sediments, and water plants in 9 important rivers and lakes of Yekaterinburg (i); to examine the ability of aquatic plants to accumulate high concentrations of heavy metals and determine their usage as a bioindicator of water pollution.

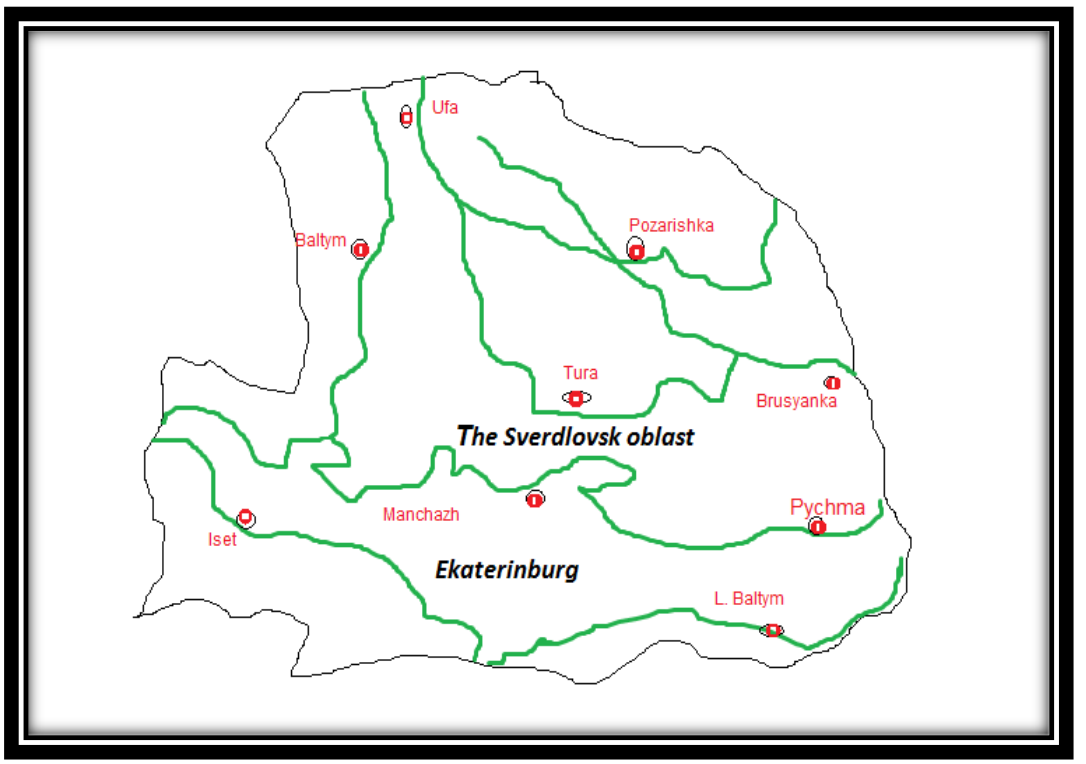


Fig.1. Study sites and sampling sites in Ekaterinburg.

\section{Materials and methods}

\section{Study area}

Table .1. List of water bodies and their location

\begin{tabular}{|c|c|c|}
\hline No. & Waterbodies & \\
\hline 1. & R. Pozarishka & Sverdlovsk region, Kamensky district \\
\hline 2. & R.Brusyanka & Sverdlovsk region, Beloyarsky district \\
\hline 3. & R.Puchma & Sverdlovsk Region, Sukholozhsky District \\
\hline 4. & R. Manchazh & Sverdlovsk region, GOG Verkhnyaya Pyshma \\
\hline 5. & R. Iset & Sverdlovsk Region, Yekaterinburg \\
\hline 6. & R. Baltym & Sverdlovsk region, GOG Verkhnyaya Pyshma \\
\hline 7. & R. Ufa & Sverdlovsk region, Krasnoufimsky district \\
\hline 8. & R. Tura & Sverdlovsk region, Nizhneturinsky district \\
\hline 9. & L. Baltym & Sverdlovsk region, GOG Verkhnyaya Pyshma \\
\hline
\end{tabular}

\subsection{Site characteristics and collection of samples.}

The examinations were carried out in Sverdlovsk region (Ekaterinburg a city) of about 1million inhabitants, where eight rivers and one lake are located (Fig. 1). These water bodies are distributed in the Sverdlovsk region, that flows in western, east and north in Sverdlovsk region (Ekaterinburg) Samples were taken from three zones, every river, 1 liter from the zone and depth $50 \mathrm{~cm}$ under surface water. The water bodies next to area agriculture, livestock animals and receives several types of industrial, and agriculture wastes from a different point and non-point sources.

This study was carried out in Eight Rivers and one lake of Sverdlovsk region; different samples (water, sediment and aquatic plants) were taken from 9 sampling sites.

Water samples were collected from every zone using 1 liter plastic bottles and transferred to the laboratory in cool boxes. The bottles were stored in $1 \%$ nitric acid (analytical grade) at $4{ }^{\circ} \mathrm{C}$ before use. A sample was taken 2 times every year from May October 2018. Aquatic plant, above-ground plant parts were collected, nine samples from aquatic plant (Ceratophyllum Demersum, Myriophyllum Sibiricum, and Lemna Turionifera). Aquatic plant transferred to the laboratory in clean plastic bags. Washed Firstly with tap water to come after by distilled water to dispose of visible debris[17,18]. The above-ground plant put in oven-dried in a hot-air oven at $70-80^{\circ} \mathrm{C}$ for $24 \mathrm{~h}$ to obtain a constant weight[19]. Then, the oven-dried material was ground to a fine powder using a stainless steel chopper. Thus, homogeneous plants were obtained. One gram of each sample was digested (wet acid digestion) with $15 \mathrm{ml}$ of concentrated HNO3, H2SO4, and HCIO4 in a ratio of $5-1-1$ at $80^{\circ} \mathrm{C}$ until a clear solution was obtained[20].

\subsection{Sample preparation}

The water samples were collected in polyethylene bottles, which were disinfected with acid before use. After collecting the water samples, they were filtered through the filter paper to remove all impurities and purify them, and then added the concentrated nitric acid 55\% $\left(\mathrm{HNO}^{3}\right)$, during the collection of water, by a clean scoop and packed in polyethylene bags, the samples were transferred to the laboratory and then dried sediment samples and placed in an oven at a temperature of $1100^{\circ} \mathrm{C}$ for 5-6 hours and grind to powder in Glass mortar. 
Then, the samples were stored in clean plastic bags until they were analyzed and assessed the concentration and accumulation of heavy metals[21].

\subsection{Methods for analyzing sediments}

Sample preparation for the atomic absorption determination of the acid-soluble "mobile" form of eight metals $(\mathrm{Mn}, \mathrm{Fe}, \mathrm{Co}, \mathrm{Ni}, \mathrm{Cu}, \mathrm{Zn}, \mathrm{Cd}, \mathrm{Pb}$ ) in the composition of bottom sediments was carried out by the method of wet mineralization in accordance with the Methodological Guidelines the definition of heavy metals [22].

Samples were thoroughly mixed and dried in a drying cabinet at a temperature of $100^{\circ}$ C. A weighed portion of $5 \mathrm{~g}$ was poured with $40 \mathrm{ml}$ of $1 \mathrm{~N} \mathrm{HNO}_{3}$ solution, evaporated, poured with $30 \mathrm{ml}$ of $1 \mathrm{~N} \mathrm{HNO}_{3}$ solution and boiled for 5 minutes. The cooled solution was filtered through a "blue ribbon" filter into a volumetric flask and the volume was brought to $50 \mathrm{ml}$ with $1 \mathrm{~N} \mathrm{HNO}_{3}$ solution. It carried out the determination of elements similar to water samples.

\subsection{Methods analysis of aquatic plants}

Sample preparation for atomic absorption determination of heavy metals in plants was carried out by dry ashing according to the Methodical Guidelines for the definition of heavy metals (1992). Samples of the biomaterial were ground, mixed, and dried in an oven at a temperature of $100^{\circ} \mathrm{C} .5 \mathrm{~g}$ weight burned in a muffle furnace with step heating up to $525^{\circ}$ $\mathrm{C}$ and calcining for 3 hours. The ash was wetted with $\mathrm{HNO}_{3}$ solution (dilution 1: 1) and dried. The residue was poured with $1 \mathrm{~N} \mathrm{HCl}$ solution, filtered through filter "blue ribbon" in a volumetric flask and the volume was made with $1 \mathrm{n} \mathrm{HCl}$ solution to $25 \mathrm{ml}$. It then carried out the determination of heavy metals as usual.

Statistical analysis of the obtained data included hierarchical cluster analysis with the subsequent construction of heat maps for metals in water and in bottom sediments. To search for mutually changing metals, the Spearman correlation was used as a measure of similarity, and Euclidean distances were used as a measure of proximity to search for patterns of rivers with a similar level of metal content. Both similarity matrices were recalculated into distance matrices, on the basis of which dendrograms of cluster analysis and the resulting heat maps were constructed using Ward's algorithm. Calculations and graphical constructions were performed using the "heat map" package [23] for the statistical program environment [24].

\section{Results}

The study results have been represented in Tables $2-4$. The concentration of heavy metals in Rivers and lake are presented in Table 2, 3 respectively, while a comparison between accumulations of heavy metals in Table 4.

(Table 2-4) Shows that iron (Fe): Iron is located in the twenty-sixth position in the order of the periodic table, and the importance of iron because it enters into the important processes of plants and animals and then leads to the growth of all living things[25]. According to the WHO report, the maximum allowable concentration of iron in water is 1.0 $\mathrm{mg} / 1$. [26]. The results of the water samples analysis showed that the concentration of iron element is less than the limit allowed by the World Health Organization, but at one point of the study is R. Tour exceeded the allowable concentration, and the concentration of iron in water ranged between 0.03 to $1.91 \mathrm{mg} / 1$, at the same time the iron concentration in aquatic plants ranges between $581-9485 \mathrm{mg} / \mathrm{kg}$. In the reports of the World Health Organization 
recommended that the allowable iron concentration in plants is $20 \mathrm{mg} / \mathrm{kg}$ [27]. The iron content exceeded the limit allowed in aquatic plants. Moreover, the iron concentration exceeded the allowable concentration in sediments and the concentration ranged between 1775 to $4471 \mathrm{mg} / \mathrm{kg}$.

Cadmium (Cd): Cadmium is classified as a 20th-century mineral and is a by-product of zinc. Soils and rocks, including coal and mineral fertilizers, contain cadmium. One of the most important uses of cadmium, used in batteries, dyes, plastics, and metal coatings[28]. The permissible concentration of cadmium in water is $0.01 \mathrm{mg} / 1$. The results showed that the concentration of cadmium in water samples ranged from 0.002 to $0.01 \mathrm{mg} / \mathrm{l}$. The concentration of cadmium was below the permissible limit in water samples. On the contrary, the concentration of cadmium in aquatic plants exceeded the limit and ranged from 0.85 to $30.30 \mathrm{mg} / \mathrm{kg}$, the maximum according to the WHO is $0.02 \mathrm{mg} / \mathrm{kg}$, while in Sediment samples cadmium concentration ranged from 0.60 to $2.60 \mathrm{mg} / \mathrm{kg}$. The results show that the concentration of cadmium exceeded the maximum allowed in aquatic plants.

Cobalt: Water samples were within the permissible limits for cobalt except for one point exceeding the permissible limit at R. Pozarishka; concentration was $0.32 \mathrm{mg} / 1$, sediment samples 38.90 and $63.50 \mathrm{mg} / \mathrm{kg}$, respectively.

Manganese (Mn): It is an important element for the growth of living beings, whether plant or animal. High concentrations cause structural and reproductive problems in mammals and also affect the lungs and brain. The results showed that the concentration of manganese in the permissible limits in the water samples was $0.01-0.02 \mathrm{mg} / 1$, and the allowable limit $(0.4 \mathrm{mg} / 1)$. While the concentration of manganese in aquatic plants and sediment samples were 9946.00 and $4684.00 \mathrm{mg} / \mathrm{kg}$, respectively.

Copper $(\mathrm{Cu})$ : The results showed that the concentration of copper in water ranges between 0.01 to $0.02 \mathrm{mg} / 1$, which is less than the allowable limit of $2 \mathrm{mg} / 1$. The maximum allowable copper content in water is; in water samples, the copper concentration is in the range. The allowable copper concentration in aquatic plants according to the World Health Organization was $10 \mathrm{mg} / \mathrm{kg}$.[29]. The concentration of copper in aquatic plants ranged between $6.30-43.70 \mathrm{mg} / \mathrm{kg}$, in some places the concentration was above the limit. In contrast, the copper concentration in the sediment was higher than the allowable limit, ranging from $10.3-101.1 \mathrm{mg} / \mathrm{kg}$.

Nickel (Ni): Nickel is a two-way weapon in the sense that at low concentrations it is an important component of plants and animals, important for regulating fat content in tissues and the formation of red blood cells. But the other side in high concentrations becomes toxic and causes many diseases, such as weight loss, loss of vision, as well as heart and liver failure, as well as skin irritation.[29]. From the results obtained it was found that the concentration of nickel ranged between 21.00 and $41.00 \mathrm{mg} / 1$, the maximum allowable content of nickel in water is $0.2 \mathrm{mg} / 1$. The nickel concentration exceeded the allowable concentrations in the water samples. Also, nickel concentrations in both aquatic plants and sediments exceeded the allowed limits and were 21.00 to $41.00 \mathrm{mg} / \mathrm{kg}, 13.80-84.50 \mathrm{mg} / \mathrm{kg}$, respectively.

Lead $(\mathrm{Pb})$ : It is one of the most toxic minerals, and as a result of its extensive use, this has resulted in serious pollution of the environment and health effects in many parts of the world [30]. Lead concentrations in all water samples were significantly lower than permissible concentrations, except for one point that exceeded the limit of R. Pozarishka, and the WHO limit was $0.05 \mathrm{mg} / \mathrm{l}$, the lead concentration was $0.06-0.13 \mathrm{mg} / \mathrm{L}$. The WHO recommended limit for aquatic plants is $2 \mathrm{mg} / \mathrm{kg}$, and the concentration of lead in aquatic plants ranges from $21.50-68.00 \mathrm{mg} / \mathrm{kg}$. In addition, the concentration in the sediment samples was above the acceptable limit in the range of $15.70-197.40 \mathrm{mg} / \mathrm{kg}$.

Mean contents comparison accumulation of different metals in water, aquatic plants, and sediment samples of Lake and rivers are presented in Table 4. Fe content concentration 
was high in Sediment Lake, while Fe content concentration in aquatic plants, sediment (rivers) was found to be considerably higher than those obtained lake. While the content of cadmium concentration in the lake and rivers ranged in the same range of concentration. Meanwhile, the content of cobalt in aquatic plants and sediments of rivers was much higher than that found in the lake. While the content of manganese concentration was high in aquatic plants and sediments of the lake, but its concentration in aquatic plants and sediments of rivers is much higher than its concentration in the lake. In the meantime, the copper concentration was high in aquatic plants and sediments of river. While the concentration of nickel was somewhat high in aquatic plants and sediments of the lake, but its concentration in aquatic plants and sediments of rivers was higher than in the lake. In the lake the decreasing trend of various metals in water was $\mathrm{Cd}>\mathrm{Cu}>\mathrm{Mn}>\mathrm{Co}>\mathrm{Fe}>\mathrm{Ni}>\mathrm{Pb}$, while for aquatic plants was $\mathrm{Cd}>\mathrm{Pb}>\mathrm{Cu}>\mathrm{Co}>\mathrm{Ni}>\mathrm{Fe}>\mathrm{Mn}$. Also, for sediment was $\mathrm{Cd}>$ $\mathrm{Co}>\mathrm{Cu}>\mathrm{Ni}>\mathrm{Pb}>\mathrm{Mn}>\mathrm{Fe}$. In the Rivers the decreasing trend of various metals in water was $\mathrm{Cd}>\mathrm{Cu}>\mathrm{Mn}>\mathrm{Ni}>\mathrm{Co}>\mathrm{Pb}>\mathrm{Fe}$. For aquatic plants $\mathrm{Cd}>\mathrm{Cu}>\mathrm{Ni}>\mathrm{Co}>\mathrm{Pb}>\mathrm{Mn}>$ Fe. Also for Sediment was $\mathrm{Cd}>\mathrm{Cu}>\mathrm{Co}>\mathrm{Ni}>\mathrm{Pb}>\mathrm{Mn}>\mathrm{Fe}$.

Table2. The concentration of heavy metals $(\mathrm{mg} / \mathrm{l})$ in rivers, S.E (absolute error with probability $\mathrm{p}=$ $0.95)(n=27)$

\begin{tabular}{|c|c|c|c|c|c|c|c|}
\hline $\begin{array}{c}\text { Water } \\
\text { sample } \\
\text { site }\end{array}$ & $\begin{array}{c}\text { Mean } \\
\text { conc. of } \\
\text { Fe in } \\
\text { mg/l } \\
\pm \text { S. E } \\
\end{array}$ & $\begin{array}{c}\text { Mean } \\
\text { conc. of } \\
\text { Cd in } \mathrm{mg} / \mathrm{l} \\
\pm \mathrm{S} . \mathrm{E}\end{array}$ & $\begin{array}{c}\text { Mean } \\
\text { conc. of } \\
\text { Co in } \\
\text { mg/l } \\
\pm \text { S. E } \\
\end{array}$ & $\begin{array}{c}\text { Mean } \\
\text { conc. of } \\
\text { Mn in } \\
\text { mg/l } \\
\pm \text { S. E } \\
\end{array}$ & $\begin{array}{c}\text { Mean } \\
\text { conc. of } \\
\mathrm{Cu} \text { in } \\
\mathrm{mg} / \mathrm{l} \\
\pm \mathrm{S} . \mathrm{E} \\
\end{array}$ & $\begin{array}{c}\text { Mean } \\
\text { conc. of } \\
\mathrm{Ni} \mathrm{in} \\
\mathrm{mg} / \mathbf{l} \\
\pm \mathrm{S} . \mathrm{E} \\
\end{array}$ & $\begin{array}{c}\text { Mean } \\
\text { conc. of } \\
\mathrm{Pb} \text { in } \\
\mathrm{mg} / \mathbf{l} \\
\pm \mathrm{S} \text {. E } \\
\end{array}$ \\
\hline $\begin{array}{c}\text { R.Pozaris } \\
\text { hka }\end{array}$ & $\begin{array}{c}0,029 \pm 0 \\
009\end{array}$ & $\begin{array}{c}0,0063 \pm 0,0 \\
019\end{array}$ & $\begin{array}{c}0,317 \pm 0 \\
079\end{array}$ & $\begin{array}{c}0,019 \pm 0 \\
006\end{array}$ & $\begin{array}{c}0,012 \pm 0 \\
003\end{array}$ & $\begin{array}{c}0,103 \pm 0 \\
026\end{array}$ & $\begin{array}{c}0,106 \pm 0 \\
027\end{array}$ \\
\hline $\begin{array}{c}\text { R.Brusya } \\
\text { nka }\end{array}$ & $\begin{array}{c}0,045 \pm 0 \\
014\end{array}$ & $\begin{array}{c}0,0047 \pm 0,0 \\
014\end{array}$ & $\begin{array}{c}0,121 \pm 0 \\
030\end{array}$ & $\begin{array}{c}0,016 \pm 0 \\
005\end{array}$ & $\begin{array}{c}0,010 \pm 0 \\
003\end{array}$ & $\begin{array}{c}0,086 \pm 0 \\
022\end{array}$ & $\begin{array}{c}0,083 \pm 0 \\
021\end{array}$ \\
\hline R. Eset & $\begin{array}{c}0,097 \pm 0 \\
029\end{array}$ & $\begin{array}{c}0,0031 \pm 0,0 \\
009\end{array}$ & $\begin{array}{c}0,138 \pm 0 \\
035\end{array}$ & $\begin{array}{c}0,013 \pm 0 \\
004\end{array}$ & $\begin{array}{c}0,006 \pm 0 \\
002\end{array}$ & $\begin{array}{c}0,035 \pm 0 \\
011\end{array}$ & $\begin{array}{c}0,062 \pm 0 \\
016\end{array}$ \\
\hline R. Baltym & $\begin{array}{c}0,064 \pm 0 \\
019\end{array}$ & $\begin{array}{c}0,0047 \pm 0,0 \\
014\end{array}$ & $\begin{array}{c}0,105 \pm 0 \\
026\end{array}$ & $\begin{array}{c}0,013 \pm 0 \\
004\end{array}$ & $\begin{array}{c}0,008 \pm 0 \\
002\end{array}$ & $\begin{array}{c}0,086 \pm 0 \\
022\end{array}$ & $\begin{array}{c}0,083 \pm 0 \\
021\end{array}$ \\
\hline R. Pishma & $\begin{array}{c}0,029 \pm 0 \\
009\end{array}$ & $\begin{array}{c}0,0015 \pm 0,0 \\
005\end{array}$ & $\begin{array}{c}0,061 \pm 0 \\
015\end{array}$ & $\begin{array}{c}0,013 \pm 0 \\
004\end{array}$ & $\begin{array}{c}0,003 \pm 0 \\
001\end{array}$ & $\begin{array}{c}0,052 \pm 0 \\
013\end{array}$ & $\begin{array}{c}0,083 \pm 0 \\
021\end{array}$ \\
\hline $\begin{array}{l}\text { R.Mancha } \\
\text { ge }\end{array}$ & $\begin{array}{c}0,045 \pm 0 \\
014\end{array}$ & $\begin{array}{c}0,0015 \pm 0,0 \\
005\end{array}$ & $\begin{array}{c}0,043 \pm 0 \\
011\end{array}$ & $\begin{array}{c}0,013 \pm 0 \\
004\end{array}$ & $\begin{array}{c}0,003 \pm 0 \\
001\end{array}$ & $\begin{array}{c}0,069 \pm 0 \\
017\end{array}$ & $\begin{array}{c}0,106 \pm 0 \\
027\end{array}$ \\
\hline R. Ufa & $\begin{array}{c}0,037 \pm 0 \\
011\end{array}$ & $\begin{array}{c}0,0047 \pm 0,0 \\
014\end{array}$ & $\begin{array}{c}0,036 \pm 0 \\
009\end{array}$ & $\begin{array}{c}0,019 \pm 0 \\
006\end{array}$ & $\begin{array}{c}0,002 \pm 0 \\
001\end{array}$ & $\begin{array}{c}0,035 \pm 0 \\
011\end{array}$ & $\begin{array}{c}0,133 \pm 0 \\
033\end{array}$ \\
\hline R. Tour & $\begin{array}{l}1,91 \\
\pm 0,29\end{array}$ & $\begin{array}{c}0,0015 \pm 0,0 \\
005\end{array}$ & $\begin{array}{c}0,024 \pm 0 \\
006\end{array}$ & $\begin{array}{c}0,019 \pm 0 \\
006\end{array}$ & $\begin{array}{c}0,003 \pm 0 \\
001\end{array}$ & $\begin{array}{c}0,035 \pm 0 \\
011\end{array}$ & $\begin{array}{c}0,083 \pm 0 \\
021\end{array}$ \\
\hline
\end{tabular}

Table3. The concentration of heavy metals (mg/l) in lake, S.E (absolute error with Probability $\mathrm{P}=$ $0.95)$

\begin{tabular}{|c|c|c|c|c|c|c|c|}
\hline $\begin{array}{c}\text { Water } \\
\text { sample } \\
\text { site }\end{array}$ & $\begin{array}{l}\text { Mean } \\
\text { conc. of } \\
\mathrm{Fe} \text { in } \\
\mathrm{mg} / \mathrm{l} \\
\pm \mathrm{S} . \mathrm{E}\end{array}$ & $\begin{array}{c}\text { Mean } \\
\text { conc. of } \\
\text { Cd in } \\
\mathrm{mg} / \mathrm{l} \pm \mathrm{S} \text {. } \\
\mathrm{E}\end{array}$ & $\begin{array}{c}\text { Mean } \\
\text { conc. of } \\
\text { Co in mg/l } \\
\pm \text { S. E }\end{array}$ & $\begin{array}{c}\text { Mean } \\
\text { conc. of } \\
\mathrm{Mn} \text { in } \\
\mathrm{mg} / \mathrm{l} \\
\pm \mathrm{S} . \mathrm{E}\end{array}$ & $\begin{array}{c}\text { Mean } \\
\text { conc. of } \\
\mathrm{Cu} \text { in } \mathrm{mg} / \mathrm{l} \\
\pm \mathrm{S} . \mathrm{E}\end{array}$ & $\begin{array}{c}\text { Mean } \\
\text { conc. of } \\
\text { Ni in mg/l } \\
\pm \text { S. E }\end{array}$ & $\begin{array}{l}\text { Mean } \\
\text { conc. of } \\
\mathrm{Pb} \text { in } \\
\mathrm{mg} / \mathrm{l} \\
\pm \mathrm{S} \text {. E }\end{array}$ \\
\hline the & $\begin{array}{l}0,074 \pm 0,0 \\
22\end{array}$ & $\begin{array}{l}0,0015 \pm 0 \\
, 0005\end{array}$ & 9 & $\begin{array}{l}0,016 \pm 0,0 \\
05\end{array}$ & $\begin{array}{l}0,006 \pm 0, \\
02\end{array}$ & $\begin{array}{l}0,052 \pm 0 \\
13\end{array}$ & $\begin{array}{l}0,062 \pm 0 \\
016\end{array}$ \\
\hline
\end{tabular}

Table 4. A comparison between accumulation of heavy metals in lake and rivers

\begin{tabular}{|l|l|l|}
\hline $\begin{array}{l}\text { Water } \\
\text { bodies }\end{array}$ & Lake & River \\
\hline
\end{tabular}




\begin{tabular}{|l|l|l|l|l|l|l|}
\hline Metals & $\begin{array}{c}\text { Water } \\
(\mathrm{mg} / \mathrm{l})\end{array}$ & $\begin{array}{c}\text { Aquatic } \\
\text { plants }(\mathrm{mg} / \mathrm{Kg})\end{array}$ & $\begin{array}{c}\text { Sediment } \\
(\mathrm{mg} / \mathrm{Kg})\end{array}$ & $\begin{array}{c}\text { Water } \\
(\mathrm{mg} / \mathrm{l})\end{array}$ & $\begin{array}{c}\text { Aquatic } \\
\text { plants(mg/Kg) }\end{array}$ & $\begin{array}{c}\text { Sediment } \\
(\mathrm{mg} / \mathrm{Kg})\end{array}$ \\
\hline $\mathrm{Fe}$ & 0,074 & 12,97 & 1775 & 0,282 & 3349,72 & 3110,222 \\
\hline $\mathrm{Cd}$ & 0,0015 & 0,24 & 1,3 & 0,003 & 1,396 & 1,378 \\
\hline $\mathrm{Co}$ & 0,157 & 2,07 & 6,0 & 0,110 & 33,18 & 45,411 \\
\hline $\mathrm{Mn}$ & 0,016 & 48,92 & 38,0 & 0,016 & 3049,62 & 921,100 \\
\hline $\mathrm{Cu}$ & 0,006 & 1,95 & 10,8 & 0,006 & 16,78 & 35,044 \\
\hline $\mathrm{Ni}$ & 0,052 & 3,87 & 13,8 & 0,062 & 33,2 & 58,378 \\
\hline $\mathrm{Pb}$ & 0,062 & 1,82 & 20,4 & 0,092 & 49 & 64,211 \\
\hline
\end{tabular}
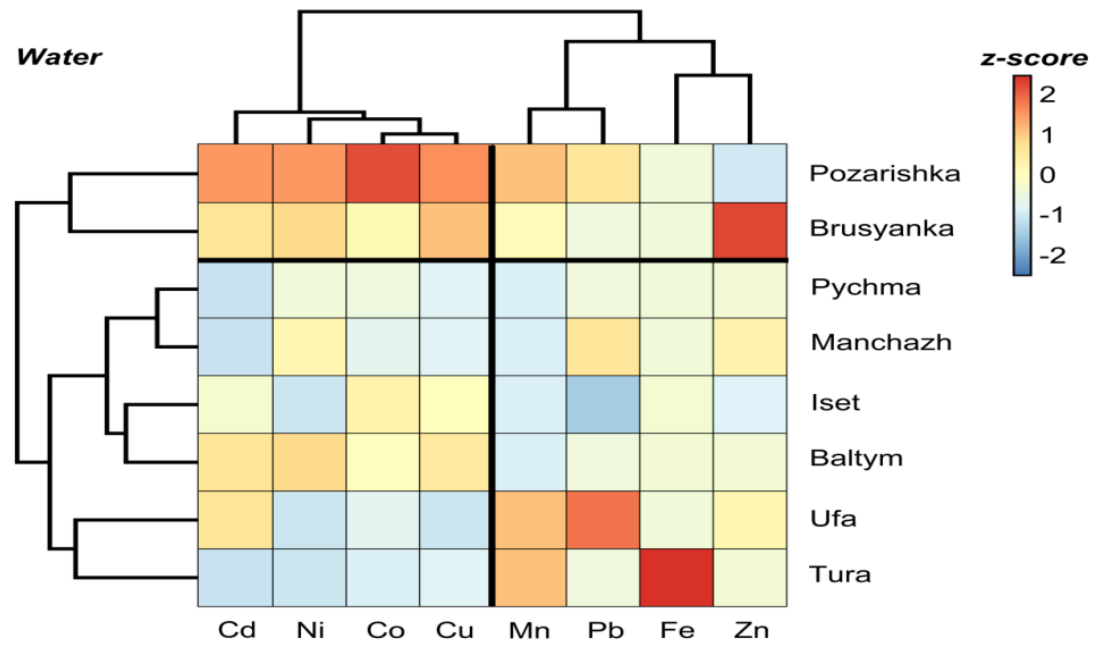

Pychma

Manchazh

Iset

Baltym

Ufa

Tura

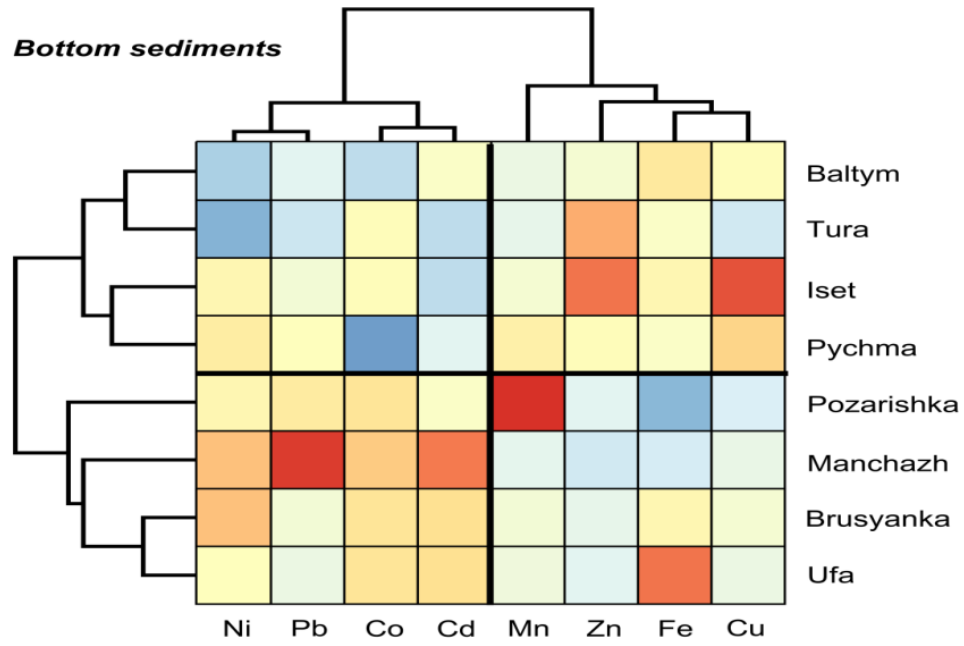

Fig. 2. Dendrograms of the similarity of heavy metals and 8 Ural rivers on heat maps

To summarize the data and compare water with bottom sediments, heat maps were constructed (Fig. 2). As can be seen from the top of Fig. 2, two patterns of metals with correlated changes in the water of $8 \mathrm{Ural}$ rivers were distinguished: 1) $\mathrm{Cd}, \mathrm{Ni}, \mathrm{Co}, \mathrm{Cu}$, and 2) $\mathrm{Mn}, \mathrm{Pb}, \mathrm{Fe}, \mathrm{Zn}$. The first metal pattern is predominantly natural Geochemical and includes elements of the weathering crust of the Ural hyperbasites $-\mathrm{Ni}, \mathrm{Co}, \mathrm{Cu}$. This association of elements is well known and is found in many Ural water bodies, especially in bottom sediments [31]. 


\section{Discussion}

This study was conducted to evaluate the concentration of heavy metals $(\mathrm{Pb}, \mathrm{Ni}, \mathrm{Co}, \mathrm{Mn}$, $\mathrm{Cu}, \mathrm{Cd}$, and $\mathrm{Fe}$ ) in water, aquatic plants, and sediments. Because water system pollution is a major threat to the aquatic ecosystem and human health, it is necessary to assess the accumulation of heavy metals in the water system (water, plants, and sediments) in rivers and lakes, as this is a very important issue that concerns all organisms and the environment. For this, 9 samples of water were collected from the surface of rivers and lakes, 9 samples of sediment and 5 water stations. The results obtained are presented in table form. After collecting and analyzing water samples to estimate the concentration of these heavy metals $(\mathrm{Pb}, \mathrm{Ni}, \mathrm{Co}, \mathrm{Mn}, \mathrm{Cu}, \mathrm{Cd}$, and $\mathrm{Fe})$, the results of the analysis showed that the concentration of heavy metals is below the limits set by the World Health Organization. But at one point of the study, R. Tour, the mineral concentration content was higher than that allowed by the World Health Organization. Agricultural and industrial wastewater is also discharged into the lake and river $[32,33]$. Moreover, it has been shown that the nickel concentration is higher than the allowable limit. This increase in nickel concentration may be due to many reasons, but the most important of these is the continuous discharge of industrial effluents and municipal wastewater without treatment in water systems. While the concentration of minerals in the lower sediments and aquatic plants there was a wide variation and showed these differences between point selections. The different metal accumulation demeanor may be connected to the intensity of human activities, such as the use of chemical fertilizers in agriculture. Municipal waste disposal, and industrial wastewater discharge[33,34]. The high concentration of $\mathrm{Fe}$ in sediment and aquatic plants because of natural or anthropogenic loading from sources such as soil erosion or the dissolution of water-soluble salts from the river[36]. The high content concentration of $\mathrm{Cu}$, Come back to Excessive use of fungicides in agriculture, Also, domestic wastewater was very likely the main source in $\mathrm{Cu}$ pollution[37]. Most copper and cadmium deposits are known to be related to pesticides, especially in freshwater ecosystem sediments $[37,38]$. Generally, the metal concentration in the sediment increases with decreasing particle size and increasing organic content[40]. A comparison of the heavy metal content in sediment and aquatic plants of the same biomes shows that their accumulation depends largely on the metal species. Consequently, the content of $\mathrm{Co}, \mathrm{Cu}, \mathrm{Ni}$ and $\mathrm{Pb}$ in sediments is higher than in aquatic plants. On the other hand, the Fe, Mn and Cd content of aquatic plants is higher than that of sediments [41,42]. The concentration of heavy metals in sediments and aquatic plants was higher than a concentration of these minerals in water samples, rivers and lakes, which ultimately lead to the concentration and accumulation of heavy metals in aquatic plants and sediments, as well as a accumulation of concentration in fish, including up maximum impact to humans, which in turn caused human diseases of various, this is consistent with the research[43]. In a report by the World Health Organization, it stated that the increase in the concentration of heavy metals in water bodies is due to the discharge of industrial waste and various types of civil pollution, this, in turn, leads to deterioration and corruption of water quality, making it unsuitable and unfit for aquatic and human life.

For the studied rivers, the correlations of $\mathrm{Co}-\mathrm{Cu}$ and $\mathrm{Ni}-\mathrm{Cu}$ in the composition of this pattern were statistically significant: Spearman's $\rho=0.854, \mathrm{P}=0.012$ and $\rho=0.792, \mathrm{P}=0.031$, respectively. It also included $\mathrm{Cd}$, which can be of both natural and man-made origin. The maximum concentrations of the elements of the first association were noted in the Pozarishka and Brusyanka rivers. The second pattern of elements is interpreted more difficult, and it is probably natural and technogenic. It includes both micronutrients $(\mathrm{Mn}$, $\mathrm{Fe}$, and $\mathrm{Zn}$ ) and xenobiotic $\mathrm{Pb}[44]$. It is possible that $\mathrm{Pb}$ and $\mathrm{Zn}$ in this pattern are of motor vehicle origin because these elements are often considered as road traffic metals[45]. The $\mathrm{Pb}-\mathrm{Zn}-\mathrm{Cd}$ association is well known in water systems[46] and was previously discovered 
by us in a number of Ural reservoirs, for example, in the Magnitogorsk Reservoir [47]. The color of the cells indicates that the highest concentration of elements of the second pattern is noted in Ufa, Tura, as well as Pozarishka and Brusyanka. So in general, according to the levels of pollution with heavy metals of various geneses, all rivers were divided into three clusters: 1) with the maximum pollution - Pozarishka and Brusyanka, 2) with an intermediate level - Pyshma, Manchazh, Iset, and Baltym and 3) with low natural and increased natural-technogenic pollution level - Ufa and Tura.

Somewhat different patterns of metals were observed in the bottom sediments of rivers (Fig. 2). As the dendrogram of cluster analysis shows, all metals were divided into two clusters: 1) xenobiotic $\mathrm{Ni}, \mathrm{Pb}, \mathrm{Co}, \mathrm{Cd}$, and 2) biotic $\mathrm{Mn}, \mathrm{Zn}, \mathrm{Fe}, \mathrm{Cu}$. Most likely, the first association is a mixture of soil $\mathrm{Ni}, \mathrm{Co}$, and technogenic (road traffic) $\mathrm{Pb}, \mathrm{Cd}$. The correlations of $\mathrm{Ni}-\mathrm{Pb}(\rho=0.812, \mathrm{P}=0.019)$ and $\mathrm{Co}-\mathrm{Cd}(\rho=0.724, \mathrm{P}=0.050)$ were statistically significant. The highest concentration of these metals was observed in the rivers Pozarishka, Manchazh, Brusyanka, and Ufa, and the smallest - in the rivers Baltym and Tura. Elements of the second association are micronutrients and accumulate in significant quantities by aquatic organisms [44]. Therefore, their coordinated change in reservoirs should correlate with the content of organic matter of autochthonous origin. From this, it follows that the highest concentration of nutrient metals was observed in the least polluted rivers: Baltym, Tura, Iset, and Pyshma. A negative correlation of metals of two patterns in river bottom sediments is manifested in $\mathrm{Co}-\mathrm{Zn}(\rho=-0.761, \mathrm{P}=0.037)$ and $\mathrm{Cd}-\mathrm{Zn}(\rho=-0.915$, $\mathrm{P}=0.004$ ) pairs. It is also clearly visible on the heat map, the field of which is divided into 4 equal parts: 2 bluer with low metal content and 2 opposing orange with high metal content. Since metals in bottom sediments reflect long-term accumulation trends, it can be assumed that the concentrations of xenobiotic heavy metals in the Pozarishka, Manchazh, Brusyanka, and Ufa rivers have a negative and limiting effect on the development of aquatic biota.

\section{Conclusions}

The main study is aimed at assessing the accumulation of heavy metals $\mathrm{Fe}, \mathrm{Cd}, \mathrm{Co}, \mathrm{Mn}, \mathrm{Cu}$, $\mathrm{Ni}$, and $\mathrm{Pb}$ in water samples, sediments, and aquatic plants. The results show that the concentration of all water samples was within acceptable limits established by WHO, while the concentration of all collected aquatic plants and sediments was above the acceptable limits of WHO. The results of this study indicate that the concentrations of heavy metals accumulation in aquatic plants and sediments are higher than those found in water samples. According to the levels of pollution with heavy metals of various geneses, all rivers were divided into three clusters: 1) with the maximum pollution - Pozarishka and Brusyanka, 2) with an intermediate level - Pyshma, Manchazh, Iset, and Baltym and 3) with low natural and increased natural-technogenic pollution level - Ufa and Tura.

\section{References}

1. Z. Todorović, P. Polić, D. Djordjević, and S. Antonijević, J. Serbian Chem. Soc., 66(10), 697-708 (2001)

2. G. Bonanno and R. Lo Giudice, Ecol. Indic., 10(3), 639-645 (2010)

3. S. Götze, A. Bose, I. M. Sokolova, D. Abele, and R. Saborowski, Comp. Biochem. Physiol, Part - C Toxicol. Pharmacol., 162(1), 62-69 (2014)

4. H. Marchner, No Title Mineral Nutrition of higher plants, H. B. T.-M. N. of H. P. (Second E. Marschner, Ed. London: Academic Press, 1995)

5. A.M. Zayed and N. Terry, Plant Soil, 249(1), 139-156 (2003) 
6. A. Göthberg, M. Greger, and B. E. Bengtsson, Environ. Toxicol. Chem., 21(9), 19341939 (2002)

7. K. Drzewiecka, K. Borowiak, M. Mleczek, I. Zawada, and P. Goliński, Acta Biol. Cracoviensia Ser. Bot., 52(2), 59-68 (2010)

8. S. E. Jørgensen, Ecol. Eng., 2(2), 89-100 (1993)

9. S. Cheng, W. Grosse, and F. Karrenbrock, Efficiency of constructed wetlands in decontamination of water polluted by heavy metals, 18, 317-325 (2002)

10. A. Galletti, P. Verlicchi, and E. Ranieri, Sci. Total Environ, 408(21), 5097-5105 (2010)

11. T. Sawidis, M. K. Chettri, A. Papaioannou, G. Zachariadis, and J. Stratis, Ecotoxicol. Environ. Saf., 48(1), 27-35 (2001)

12. Y. Ruilian, Y. Xing, Z. Yuanhui, H. Gongren, and T. Xianglin, J. Environ. Sci., 20, 664-669 (2008)

13. C. K. Jain, D. C. Singhal, and M. K. Sharma, Environ. Monit. Assess., 105(1-3), 193207 (2005)

14. P. Cooper and B. Green, Water Sci. Technol., 32(3), 317-327 (1995)

15. A. Milošković, S. Branković, V. Simić, S. Kovačević, M. C̈irković, and D. Manojlović, Bull. Environ. Contam. Toxicol., 90(5), 563-569 (2013)

16. V. J. Odjegba, M. T. Brown, and A. Turner, Am. J. Plant Physiol., 2(3), 183-194 (2007)

17. D. Sheehan, J. O'Halloran, A. R. Walsh, and P. J. Fitzpatrick, Bioremediation Protoc., 2, 201-212 (2003)

18. R. Sadler and G. Rynja, Preservation, storage, transport, analysis and reporting of water samples, Queensland government chemical laboratory report, series 12, (Brisbane Queensl. Gov. Publ., 1992)

19. C. R. Campbell and C. O. Plank, Methods Plant Anal.,37 (1998)

20. S. E. Allen, H. M. Grimshaw, and A. P. Rowland, Chemical analysis. Methods in plant ecology, Black Well, 285-344 (1986)

21. L. J. Duivenvoorden, D. T. Roberts, and G. M. Tucker, Environ. Earth Sci., 76(8) (2017)

22. Methodological Guidelines on Determination of Heavy Metals in Agricultural Soils and Crop Produce (1992)

23. R. Kolde, Pheatmap: pretty heatmaps. R package version 1.0.12.2019

24. T. RCore, $R$ : a language and environment for statistical computing. R Foundation for Statistical Computing (Vienna, Austria, 2016)

25. M. Valko, H. Morris, and M. Cronin, Curr. Med. Chem., 12(10), 1161-1208, 2005

26. G. Patil and I. Ahmad, Acta Chim. Pharm. Indica Acta Chim. Pharm. Indica, 1(1), 7-9, (2011)

27. A. Shah et al., Comparative Study of Heavy Metals in Soil and Selected Medicinal Plants (2013)

28. S. Martin and W. Griswold, Environ. Sci. Technol. Briefs, 15, 1-6 (2009)

29. R. Nazir, M. Khan, M. Masab, H. U. R. Rehman, and N. U. R. Rauf, Accumulation of Heavy Metals ( $\mathrm{Ni}, \mathrm{Cu}, \mathrm{Cd}, \mathrm{Cr}, \mathrm{Pb}, \mathrm{Zn}, \mathrm{Fe}$ ) in the soil, water and plants and analysis of physico-chemical parameters of soil and water Collected from Tanda Dam kohat, 7(3), 89-97 (2015) 
30. M. Jaishankar, T. Tseten, N. Anbalagan, B. B. Mathew, and K. N. Beeregowda, Interdiscip. Toxicol., 7(2), 60-72 (2014)

31. D. Y. Nokhrin, Y. G. Gribovskii, and N. A. Davydova, Water Resour., 35(5), 542-549 (2008)

32. I. M. Donnik, I. A. Shkuratova, A. G. Isaeva, and N. A. Vereshchak, "Krivonogova AS, Beykin YB, Portnov VS, Barashkin MI, Loretts, Agrar. Bull. Ural., 1, 26-28 (2012)

33. A. Universio, Water, 413-429 (1997)

34. H. Long, J. Zou, and Y. Liu, Habitat Int., 33(4), 454-462 (2009)

35. E. D. Ongley, Z. Xiaolan, and Y. Tao, Environ. Pollut., 158(5), 1159-1168 (2010)

36. V. Dummee, M. Kruatrachue, W. Trinachartvanit, P. Tanhan, P. Pokethitiyook, and P. Damrongphol, Ecotoxicol. Environ. Saf., 86, 204-212 (2012)

37. N. S. PAO, ScienceAsia, 39(2), 105-110 (2012)

38. M. O. Gutova and M. S. A. Kh. E. Flefel, Agrar. Bull., 198(7), 41-46 (2020)

39. D. Baršytė Lovejoy, Acta Zool. Litu., 9(2), 12-20, 1999.

40. D. W. Mackay and I. Thornton, J. Mar. Biol. Assoc. United Kingdom, 53(3), 721-739, 1973

41. H.E. Flefel, D.Yu. Nokhrin, and I. M.Donnik, Chemical composition and water quality of some rivers of the sverdlovsk oblast (Ural, Russia), 434(2014), 138-142 (2019)

42. T., Chettri, M.K., Zachariadis, G.A. \& Stratis, Heavy metals in aquatic plants and sediments from water systems in Macedonia, Greece, 73-80 (J. A. SAWIDIS,1995)

43. H. Zaigham, A. Zubair, K. K. Usman, I. Mazhar, K. R. Ullah, and J. Z. K. Khattak, Res. J. Environ. Earth Sci., 4, 334-339 (2012)

44. J. W. Moore, S, Ramamoorthy, Heavy metals in natural waters (Springer-Verlag, 1983)

45. C. Johansson, M. Norman, and L. Burman, Atmos. Environ., 43(31), 4681-4688 (2009)

46. J. H. Charlesworth, The Old Testament Pseudepigrapha (Hendrickson Publishers, 2010)

47. D. Y. Nokhrin, Y. G. Gribovskii, E. V. Sokol, N. A. Davydova, and E. N. Nigmatulina, Contemp. Probl. Ecol., 3(4), 487-494 (2010) 